\title{
DETERMINATION OF SOME AGRONOMIC AND QUALITY TRAITS OF PEANUT VARIETIES WITH DIFFERENT POD CHARACTERISTICS AT DIFFERENT HARVESTING TIMES IN MAIN CROP GROWING SEASON
}

\author{
Halil BAKAL , Halis ARIOGLU \\ Cukurova University, Faculty of Agriculture, Department of Field Crops, Adana, TURKEY \\ ${ }^{*}$ Corresponding author: hbakal@cu.edu.tr
}

Received: 07.03.2020

\begin{abstract}
The objective of this study was to determine the agronomic and quality traits of peanut varieties having different pod characteristics at different harvesting times in the main crop growing season. This study was conducted in the experimental area of the Cukurova University Faculty of Agriculture Department of Field Crops as a main crop in 2015 and 2016. The experimental design was a split plots with three replications. Five peanut varieties, Halisbey, NC-7, G.Green, Florispan and G.Red, belonging to four different market types, were used as plant material. Based on two year average, the differences between the varieties were significant for the investigated traits harvested at different times in the main crop growing season. The results indicated that the means of pod number and pod weight per plant, 100 seed weight, shelling percentage, pod and kernel (seed) yield per hectare, oil percentage and crude oil yield per hectare were increased except protein content of seed when the harvesting was delayed,
\end{abstract}

Keywords: Agronomic Traits, Harvesting Time, Main Crop, Peanut, Pod Characteristics

\section{INTRODUCTION}

Peanut seed is an important source of edible oil and protein for human nutrition due to containing $35-56 \%$ oil, $25-30 \%$ protein and $9.5-19.0 \%$ carbohydrate. In addition, it is a good source of mineral and vitamins (Gulluoglu, 2011; Arioglu et al., 2014; Chamberlin et al., 2014; Chowdhury et al., 2015). At present, peanut is cultivated more than 40 countries in the world. The annual peanut production is around 30.1 million tons and it contributes $5.2 \%$ of the total oil seeds production in the world in 2017/2018 growing period (Anonymous, 2018). The peanut seed has several uses. $53 \%$ of the world peanut production uses for the oil production, $32 \%$ for the peanut butter, confectionary and roasted and the remaining $15 \%$ seedcake after oil extraction is used as feed for livestock. (Liao ve Holbrook, 2007). For these reason, Peanut (Arachis hypogaea L.) is an important oilseed crop for vegetable oil production in the world. Peanut production is getting important crop by year to year. Peanut production was 166.383 ton in Turkey in 2018 and all of them are used for the human nutrition (roasted peanut).

Ketring et al. (1982) and Gulluoglu et al. (2017) indicated that the temperature plays a critical role in the growth and development of peanut plants and it appears that optima are different depending on the phase (reproductive and vegetative) of development. Peanut plant has indeterminate growth habit and the plants produced many flowers during the growing period, but only $15-20 \%$ of flowers produced mature pods (Lim and Hamdan, 1984; Ishag, 2000; Jordan et al., 2008; Kaba et al., 2014 and Arioglu, 2014). Duncan et al. (1978) and Williams (2000) suggested that the length of the filling period and the rate of pod establishment best explain the variation in peanut yield.

Canavar and Kaynak (2013), Gulluoglu et al. (2016) and Arioglu et al. (2018) reported that total pod production continually increased with growth period, but that harvested yield reached a peak and then declined due to increased field losses at delayed the harvesting date. They also reported that pod number and pod yield per plant, 100-seed weight, shelling percentage, oil content and pod yield per hectare were increased by delaying the harvesting time. Oil and protein content is an important quality characteristic in peanut seed. These two characteristics of peanut seed influence by genotypic variation, growing conditions and maturity. The oil content of peanut varieties was increased by delaying the harvesting times (Lu et al., 1997; Canavar and Kaynak, 2013). Gulluoglu et al. (2016) and Arioglu et al. (2018) reported that the protein content of the peanut seed was decreased by the harvesting time delayed. Mortley et al. (2004) findings suggested that vegetative and reproductive growth, as well as oil content of peanut in controlled environments are best at warmer temperatures of $28 / 24{ }^{\circ} \mathrm{C}$ 
to $32 / 28^{\circ} \mathrm{C}$ than at cooler temperature of $20 / 16^{\circ} \mathrm{C}$ to $24 / 20^{\circ} \mathrm{C}$

Wright and Porter (1991) indicated that harvesting peanut too early can reduce yield by $15 \%$ and economic value by $21 \%$. For this reason, it is very important to harvest the peanut plant at an appropriate time in order to reduce yield losses. Mixon and Branch (1985) and Arioglu et al. (2018) reported that pod yields of peanut varieties increased when the harvest date delayed. The objective of this study was to determine the agronomic and quality properties of peanut varieties having different pod characteristics at different harvesting times in the main crop growing season in Mediterranean Region of Turkey.Text of the introduction.

\section{MATERIALS AND METHODS}

Material
This experiment was conducted at the Research Farm of Cukurova University,Adana Turkey in the Southern Turkey, $36^{\circ} 591 \mathrm{~N}, 35^{\circ} 181 \mathrm{E}$ and $23 \mathrm{~m}$ elevation, as a main crop in 2015 and 2016. Halisbey (Virginia), NC-7 (Virginia), G.Green (Runner), Florispan (Spanish) and G.Red (Valencia) peanut varieties belonging to different market types were used as a plant material.

The soil texture was clay loam. The soil tests indicated that $\mathrm{pH}$ of 7.7 with high concentrations of $\mathrm{K}_{2} \mathrm{O}$ and low concentrations of $\mathrm{P}_{2} \mathrm{O}_{5}$. In addition, the organic matter and nitrogen content of the soil were very low. The lime content was $20.1 \%$ in the soil.

In the region, winters are mild and rainy, whereas summers are dry and warm, which is a typical of a Mediterranean climate. The climate data during the 20152016 growing period and long term (LT) average (19822015) was shown in Table 1.

Table 1. The climate data during the growing period in 2015, 2016 and long term (LT) average (1982-2015) (Anonymous, 2017)

\begin{tabular}{lccccccccc}
\hline \multirow{2}{*}{ Months } & \multicolumn{3}{c}{ Average temperature $\left({ }^{\circ} \mathrm{C}\right)$} & \multicolumn{3}{c}{ Precipitation $(\mathrm{mm})$} & \multicolumn{3}{c}{ Relative humidity $(\%)$} \\
\cline { 2 - 9 } & $\mathbf{2 0 1 5}$ & $\mathbf{2 0 1 6}$ & LT & $\mathbf{2 0 1 5}$ & $\mathbf{2 0 1 6}$ & LT & $\mathbf{2 0 1 5}$ & $\mathbf{2 0 1 6}$ & LT \\
\hline April & 16.9 & 20.5 & 17.5 & 21.5 & 1.8 & 51.3 & 61.2 & 59.2 & 67.6 \\
May & 22.5 & 22.6 & 21.7 & 65.7 & 87.9 & 47.3 & 64.8 & 69.3 & 67.3 \\
June & 25.0 & 27.1 & 25.6 & 4.8 & 45.6 & 20.4 & 69.6 & 66.1 & 68.0 \\
July & 28.4 & 29.5 & 28.2 & 0.4 & 0.2 & 6.3 & 69.8 & 67.5 & 71.4 \\
August & 30.0 & 30.9 & 28.7 & 10.9 & 0.0 & 5.6 & 63.4 & 69.0 & 70.8 \\
September & 28.4 & 26.3 & 26.1 & 13.0 & 34.8 & 17.8 & 64.8 & 61.8 & 63.2 \\
October & 23.4 & 23.1 & 21.6 & 32.1 & 0.0 & 42.1 & 63.7 & 56.4 & 59.5 \\
\hline
\end{tabular}

The mean monthly air temperature during the research period (April-October) was varied between 16.9 and 30.0 ${ }^{\circ} \mathrm{C}$ in 2015 , whereas it was 20.5 and $30.9^{\circ} \mathrm{C}$ in 2016 . The average air temperature was the higher during the research period in both years than long term average temperature. The total rainfall was $148.4 \mathrm{~mm}$ and $170.3 \mathrm{~mm}$ during the growing period in 2015 and 2016, respectively. The average relative humidity was ranged from $61.2 \%$ to $69.8 \%$ in 2015 and $56.4 \%$ to $69.3 \%$ in 2016 . The differences between the years and long term for the climate data were not found very significant (Table 1).

\section{Method}

The field trial was arranged in a split plot design (harvesting times as main plots and varieties as subplots) with three replications. $300 \mathrm{~kg} \mathrm{ha}^{-1}$ of Di-ammonium phosphate $\left(54 \mathrm{~kg} \mathrm{ha}^{-1} \mathrm{~N}, 138 \mathrm{~kg} \mathrm{ha}^{-1} \mathrm{P}_{2} \mathrm{O}_{5}\right.$ ) fertilizer was applied and incorporated to soil before planting. Ammonium nitrate $(33 \% \mathrm{~N})$ at the rates of $400 \mathrm{~kg} \mathrm{ha}^{-1}$ was applied two times; before first (beginning of flowering) and second (pod formation) irrigation $\left(200 \mathrm{~kg} \mathrm{ha}^{-1}+200\right.$ $\mathrm{kg} \mathrm{ha}^{-1}$ ) in each years. Individual plots consisted of 4 rows $5.0 \mathrm{~m}$ long and $70 \mathrm{~cm}$ apart. The seeds were sown in line manually by hand on first week of April (5 April) and with $70 \times 15 \mathrm{~cm}$ distance in both years. During the growing period, recommended pesticides and fungicides were applied to control insects and diseases. The remaining cultural practices were applied during the growing period. The plants were harvested by hand at five different times with ten days intervals after sowing (130 DAS, 140 DAS,
150 DAS, 160 DAS and 170 DAS) at the beginning of September in 2015 and 2016.

Data collection and analysis: The data belonging to agronomic and quality characteristics such as pod number and pod weight per plant, shelling percentage, 100-seed weight, pod and kernel yield per hectare, oil and protein content were recorded in each harvesting time with ten days intervals using 20 plants (Arioglu et al., 2018).

The data collected the characteristics measured were analyzed by applying standard procedures of analysis of variance to control the significance of mean squares by the F -test using JMP 8.1.0 package program with split plot design. The significant means were compared by the LSD test as described by Steel and Torrie (1980).

\section{RESULTS AND DISCUSION}

The significance of $F$ values of the variation for traits are shown in Table 2.

It could be seen in Table 2 that harvest time, variety and harvest time $\mathrm{x}$ variety interaction source of variation had highly significant $F$ values. Year x Harvest Time and Year $\mathrm{x}$ variety interaction had insignificant $\mathrm{F}$ values. For that reason means over two years will be used in presenting the results.

The means of characteristics of peanut varieties at different harvesting times were presented in Tables 3 and 4 
Table 2. Significance of $F$ values of the variation for traits based on the combined analysis of variance over two years

\begin{tabular}{lccccc}
\hline \multicolumn{1}{c}{ Trait } & Harvest Time (HT) & Variety & HT x V & Year x HT & Year x V \\
\hline Pod number & $* *$ & $* *$ & $* *$ & $\mathrm{~ns}$ & \\
Pod weight & $* *$ & $* *$ & $* *$ & $\mathrm{~ns}$ & $\mathrm{~ns}$ \\
100-Seed weight & $* *$ & $* *$ & $* *$ & $\mathrm{~ns}$ & $\mathrm{~ns}$ \\
Shelling percentage & $* *$ & $* *$ & $* *$ & $\mathrm{~ns}$ & $\mathrm{~ns}$ \\
Pod yield & $* *$ & $* *$ & $* *$ & $\mathrm{~ns}$ & $\mathrm{~ns}$ \\
Kernel yield & $* *$ & $* *$ & $* *$ & $\mathrm{~ns}$ & $\mathrm{~ns}$ \\
Oil Content & $* *$ & $* *$ & $* *$ & $\mathrm{~ns}$ & $\mathrm{~ns}$ \\
Protein content & $* *$ & $* *$ & $* *$ & & $\mathrm{~ns}$ \\
\hline
\end{tabular}

**: significant at the 0.01 probability level, ns: not significant

Table 3. The average pod number and pod weight per plant, 100-seed weight, shelling percentage and maturity index values of some peanut varieties at different harvesting times

\begin{tabular}{lcccc}
\hline $\begin{array}{l}\text { Harvesting } \\
\text { Times }(\mathbf{A})\end{array}$ & $\begin{array}{c}\text { Pod number } \\
\left(\text { no plant }^{-1}\right)\end{array}$ & $\begin{array}{c}\text { Pod weight } \\
\left(\mathrm{g} \mathrm{plant}^{-1}\right)\end{array}$ & $\begin{array}{c}\text { 100-Seed weight } \\
(\mathrm{g})\end{array}$ & $\begin{array}{c}\text { Shelling percentage } \\
(\%)\end{array}$ \\
\hline 130 DAS & 30.6 & 45.5 & 88.6 & 64.33 \\
140 DAS & 32.4 & 50.0 & 89.8 & 65.99 \\
150 DAS & 33.7 & 54.2 & 91.2 & 67.63 \\
160 DAS & 35.9 & 59.9 & 93.9 & 69.86 \\
170 DAS & 37.9 & 65.6 & 95.7 & 71.69 \\
LSD $\left(\% 5_{\mathrm{A}}\right)$ & 0.86 & 1.46 & 1.37 & 0.401 \\
Varieties $(\mathbf{B})$ & & & & 59.79 \\
Halisbey & 33.8 & 79.3 & 131.2 & 69.55 \\
NC-7 & 24.4 & 48.1 & 123.7 & 74.27 \\
G.Green & 54.4 & 54.6 & 62.4 & 69.94 \\
Florispan & 29.2 & 42.2 & 49.1 & 65.93 \\
G.Red & 28.7 & 51.1 & 92.7 & 0.290 \\
LSD $\left(\% 5_{\mathrm{B}}\right)$ & 0.90 & 1.50 & 1.21 & 0.649 \\
LSD $\left(\% 5_{\mathrm{AxB}}\right)$ & 2.00 & 3.35 & 2.51 & \\
\hline
\end{tabular}

It can be seen in Table 3 that differences between the harvesting times for the pod number per plant were statistically significant. While the pod number was 30.6 pods plant ${ }^{-1}$ when the plants harvested at the 130 DAS, it was increased to 37.9 pods plant ${ }^{-1}$ plants harvested at the 170 DAS in a two-year average. Peanut plant has indeterminate growth habit and the plants produced many flowers and pods during the growing period (Ishag, 2000); Jordan et al., 2008; Kaba et al., 2014). For this reason, the pod number was increased when the harvesting delayed. Young et al. (1982) reported that total pod production continually increased with growth period. Canavar and Kaynak (2013), Gulluoglu et al. (2016) and Arioglu et al. (2018) reported that pod production was increased by delaying the harvesting time. Arioglu et al. (2018) findings suggested that according to a two-year average the highest pod number per plant (21.0 pods plant-1) was obtained when the plants were harvested at 170 DAS in Mediterranean region.

The pod number per plant of peanut varieties varied between 24.4-54.4 pods plant ${ }^{-1}$ in a two-year average. As it can be seen in Table 3, there are big differences between the pod numbers of the peanut varieties. These differences between the varieties were found statistically significant. Among the peanut varieties, the highest pod number was obtained from G.Green (54.4 pods plant $\left.{ }^{-1}\right)$ and the lowest from NC-7 (24.4 pods plant ${ }^{-1}$ ) varieties in a two-year average (Table 3). The number of pods of peanut varieties depends on their growing characteristics (Erect, Semispreading and Spreading). The pod number of the runner type peanut varieties was higher than the other market types. Arioglu et al. (2018) found that the pod number of peanut was the highest in runner type varieties. Interaction between the harvesting times and varieties for the pod number were significant in both years. Pod number of the varieties ranged from 23.1 to 60.9 no plant $^{-1}$.The highest pod number value (60.9 no plant $\left.^{-1}\right)$ was obtained from the harvest of G.green variety made at the 170 DAS in a twoyear average (Figure 1). These results are in agreement with the findings of Arslan (2005); Calıskan et al. (2008a); Canavar ve Kaynak (2008); Canavar and Kaynak (2010); Sarkees (2015); Gulluoglu et al. (2016); Hatipoglu et al. (2017); Kumar et al. (2017) and Arioglu et al. (2018).

According to a two-year average, the differences between the harvesting times and peanut varieties were statistically significant for the pod weight per plant. The pod weight per plant values varied between 45.5-65.6 g plant $^{-1}$ in a two-year average. The pod weight of the peanut varieties was increased when the harvesting time delayed. Pod number and 100-seed weight is important factors for the pod weight per plant. It can be seen in 
Table 3, pod number per plant and 100 seed weight was increased when the harvesting time delayed. For this reason, the pod weight per plant was increased by delaying the harvesting time (Young et al., 1982; Arioglu, 2014; Gulluoglu et al., 2016; Arioglu et al., 2017). While the pod weight was $45.5 \mathrm{~g} \mathrm{plant}^{-1}$ when the plants harvested at $130 \mathrm{DAS}$, it increased to $65.6 \mathrm{~g} \mathrm{plant}^{-1}$ when the harvesting delayed to 170 DAS. Duncan et al. (1978) and Williams (2000) suggested that the length of the filling period and the rate of pod establishment best explain the variation in peanut pod weight and yield. Gulluoglu et al. (2016) and Arioglu et al. (2018) reported that the pod weight per plant was increased by delaying the harvesting time. Young et al. (1982) reported that total pod production continually increased with growth period. Canavar and Kaynak (2013) reported that, pod number and pod yield per plant, 100-seed weight, shelling percentage, pod yield, oil and protein content were increased by delaying the harvesting time.

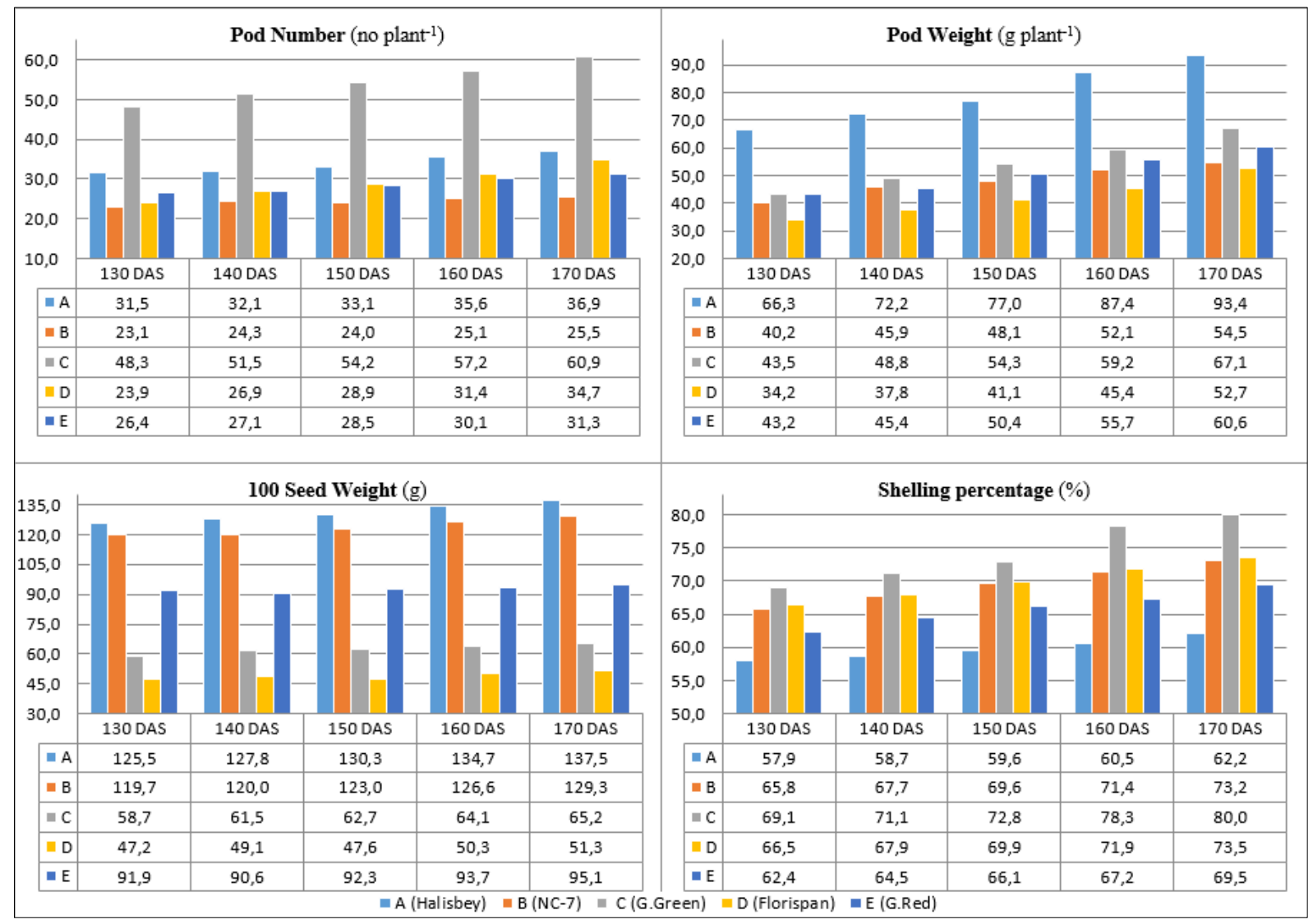

Figure 1. Interaction between the harvesting times and varieties for the pod number and weight, 100 seed weight and shelling percentage values in two years avarage

Based on two-year average, pod weight per plant of peanut varieties varied between 42.2-79.3 $\mathrm{g}_{\text {plant }}{ }^{-1}$. The pod weight was the highest for Halisbey $\left(79.3 \mathrm{~g} \mathrm{plant}^{-1}\right)$ and the lowest in Florispan (42.2 $\left.\mathrm{g} \mathrm{plant}^{-1}\right)$ varieties (Table 3). Halisbey, Virginia market type has large seeds and Florispan, Spanish market type, has small seeds. For this reason, pod weight per plant was higher in Halisbey than the others varieties. The differences for the pod weight per plant among peanut cultivars were attributed to based genetic variation of the genotypes. Interaction between the harvesting times and varieties for the pod weight were significant in both years. Pod weight of the varieties ranged from 34.1 to $93.4 \mathrm{~g} \mathrm{plant}^{-1}$. The highest pod number value (93.4 $\mathrm{g}$ plant $^{-1}$ ) was obtained from the harvest of Halisbey variety made at the 170 DAS in a twoyear average (Figure 1). Gulluoglu et al. (2017) finding suggested that the pod weight of the peanut varieties varied between $40.50-95.55 \mathrm{~g} \mathrm{plant}^{-1}$ in main crop growing period in Cukurova region. Arioglu et al. (2018) reported that the pod weight per plant value varied between 31.6-74.7 g plant-1 in main crop growing period in Mediterranean region. Similar results was found by some researchers (Canavar and Kaynak, 2008; Rahmianna et al., 2009; Kaba et al., 2014; Gulluoglu et al., 2016; Gulluoglu et al., 2017 and Arioglu et al., 2018).

There was statistically significant difference in 100seed weights between the harvesting times in a two-year average. According to two-year average, the 100-seed weight values varied between 88.6-95.7 g. The 100-seed weight of the peanut varieties was increased to $95.7 \mathrm{~g}$ when the harvesting time delayed to 170 DAS from 130 DAS (Table 3). Duncan et al. (1978) reported that the length of pod filling period correlated with the 100 -seed weight. When the harvesting time was delayed, the 100seed weigh was increased due to pod filling period was 
increased. Canavar and Kaynak (2013), Gulluoglu et al. (2016) and Arioglu et al. (2018) reported that 100-seed weight of the peanut varieties was increased when the pod filling period extended by delaying the harvesting time in peanut production. Arioglu et al. (2018) findings suggested that the 100-seed weight of peanut varieties was $119.5 \mathrm{~g}$ when the harvesting was $149 \mathrm{DAS}$ and it increased to $128 \mathrm{~g}$ at the harvesting was delayed to 170 DAS in main crop growing season.

According to a two-year average, 100-seed weight of peanut varieties varied between 49.1-131.2 g. The 100seed weight was the highest in Halisbey (131.2 g) and the lowest in Florispan (49.1 g) varieties (Table 3). The seeds are smaller in Runner, Spanish and Valencia market type peanut varieties than in Virginia type varieties. Halisbey and NC-7 varieties belong to Virginia groups. For this reason, 100-seed weight was the highest in these two varieties. The other varieties such as G.Green, Florispan and G.Red belong to Runner, Spanish and Valencia market type. The differences for the 100-seed weigh among the peanut varieties were attributed due to variation of the genotypes. Interaction between the harvesting times and varieties for the 100-seed weight were significant in both years. 100-seed weight of the varieties ranged from 47.2 to $137.5 \mathrm{~g}$. The highest pod number value $(137.5 \mathrm{~g})$ was obtained from the harvest of Halisbey variety made at the 170 DAS in a two-year average (Figure 1). Arioglu et al. (2018) found that the 100 -seed weight of peanut varieties (Virginia market type) varied between 108.1-135.7 $\mathrm{g}$ in main crop growing conditions in Mediterranean region. Gulluoglu et al. (2017) reported that the 100 -seed weight of peanut varieties was affected by the environment conditions during the growing period and genetic background. They suggested that while the 100 -seed weight of the varieties were $114.08 \mathrm{~g}$ in main crop growing season it was increased to $115.20 \mathrm{~g}$ in double crop growing season in a two-year average. These results were obtained in this research are in agreement with the findings of Wang et al. (2013), Sharma et al. (2013), Sarkees et al. (2015), Gulluoglu et al. (2016), Gulluoglu et al. (2017), Hatipoglu et al. (2017) and Arioglu et al. (2018).

As it can be seen in Table 3, the shelling percentage of peanut varieties was ranged from $64.33 \%$ to 71.69 at different harvesting times in a two-year average. The differences between the harvesting times and varieties were statistically significant for the shelling percentage. Shelling percentage of peanut varieties was increased by delaying the harvesting time. Shelling percentage of the varieties was increased from $64.33 \%$ for the first harvesting time (130 DAS), to $71.69 \%$ for the last harvesting time (170 DAS) in a two-year average. When the harvesting time was delayed, the pod filling period extended and the pods fully matured. For this reason, the shelling percentage was increased when the harvesting time delayed. Gulluoglu et al. (2016) and Arioglu et al. (2018) findings suggested that the shelling percentage of the peanut varieties was increased when the harvesting time delayed.
Based on a two-year average, the shelling percentage of the peanut varieties varied between $59.79-74.27 \%$. The shelling percentage was the highest in G.Green $(74.27 \%)$ and the lowest in Halisbey $(59.77 \%$ ) varieties (Table 3 ). Generally, the shelling percentage was the lower in Virginia market type varieties compared to other market types. Gulluoglu et al. (2017) found that the shelling percentage of the peanut varieties was the $68.82 \%$ in main crop growing conditions in Cukurova region. The differences between the varieties for the shelling percentage value originated from their genotypic background. Interaction between the harvesting times and varieties for the shelling percentage were significant in both years. Shelling percentage of the varieties ranged from 57.9 to $80.0 \%$. The highest shelling percentage value $(80.0 \%)$ was obtained from the harvest of G.Green variety made at the 170 DAS in a two-year average (Figure 1). Similar result reported by some other researches (Canavar and Kaynak, 2008; Canavar and Kaynak, 2010; Halder and Panda, 2014; Canavar and Kaynak, 2013; Gulluoglu et al., 2016; Gulluoglu et al., 2017; Kumar et al., 2017; Zuza et al., 2017 and Arioglu et al., 2018).

Based on average of two years, the differences between the harvesting times were statistically significant for the pod yield per hectare. The pod yield per hectare value varied between $3257-5151 \mathrm{~kg} \mathrm{ha}^{-1}$ in a two-year average. The pod yield of the varieties was increased when the harvesting time delayed. The pod yield was $3257 \mathrm{~kg} \mathrm{ha}^{-1}$ when the plants harvested at the $130 \mathrm{DAS}$, it increased to $5151 \mathrm{~kg} \mathrm{ha}^{-1}$ at the harvesting delayed to 170 DAS in a two-year average (Table 4). The total pod yield was increased $58.2 \%$ when the harvesting delayed 40 days after first harvesting time (130 DAS). Peanut plant has indeterminate growth habit and the plants produced many flowers and pods during the growing period (Lim and Hamdan, 1984; Ishag, 2000; Jordan et al., 2008 and Kaba et al., 2014). Flowering and pod formation continues as a long time during the growing period in peanut plants. For this reason, pod yield was increased by delaying the harvesting time. Duncan et al. (1978) and Williams (2000) suggested that the length of the filling period and the rate of pod establishment best explain the variation in peanut yield. Canavar and Kaynak (2013), Gulluoglu et al. (2016) and Arioglu et al. (2018) reported that total pod production continually increased with growth period, but that harvested yield reached a peak and then declined due to increased field losses at delayed the harvesting date. They also reported that pod number and pod yield per plant, 100-seed weight, shelling percentage, oil content and pod yield per hectare were increased by delaying the harvesting time. Park and Oh (1992) found that the pod yield was positively correlated to pod number, matured seed percent and 100 seed weight. Rahmianna et al. (2009) reported that harvesting timed significantly affected weight of pods and shelling percentage. They also reported that the yield was increased $14.3 \%$ when the harvest delayed 10 days. Court et al. (1984) indicated that the pod yield increased (48.2\%) when the harvest delayed from 2 September to 12 October. Gulluoglu et al. (2016) reported that, the pod yield was increased $31.0 \%$ when the 
harvesting time delayed from 148 DAP to 180 DAP. Arioglu et al. (2018) finding suggested that, the pod yield was increased $35.8 \%$ when the harvesting time delayed from 149 DAS to 170 DAS. Court et al. (1984), Williams et al. (1981), Knauft et al. (1986), Timmannavar et al.
(2003), Arslan (2005), Caliskan et al. (2008b), Sharma et al. (2013) and Zuza et al. (2017) reported that the pod yield was increased when the harvesting delayed in peanut production.

Table 4. The average pod and kernel weight per hectare, oil and protein content values of some peanut varieties at different harvesting times

\begin{tabular}{lcccc}
\hline $\begin{array}{l}\text { Harvesting } \\
\text { Times (A) }\end{array}$ & $\begin{array}{c}\text { Pod yield } \\
\left(\mathrm{kg} \mathrm{ha}^{-1}\right)\end{array}$ & $\begin{array}{c}\text { Kernel yield } \\
\left(\mathrm{kg} \mathrm{ha}^{-1}\right)\end{array}$ & $\begin{array}{c}\text { Oil Content } \\
(\%)\end{array}$ & Protein content $(\%)$ \\
\hline 130 DAS & 3257 & 2096 & 45.80 & 26.61 \\
140 DAS & 3585 & 2367 & 46.49 & 25.90 \\
150 DAS & 4075 & 2757 & 47.08 & 25.59 \\
160 DAS & 4688 & 3275 & 47.69 & 25.04 \\
170 DAS & 5151 & 3693 & 48.98 & 24.67 \\
LSD $\left(\% 5_{\mathrm{A}}\right)$ & 96.9 & 46.0 & 0.137 & 0.126 \\
Varieties $(\mathbf{B})$ & & & & 26.24 \\
Halisbey & 5866 & 3508 & 47.72 & 24.97 \\
NC-7 & 4383 & 3049 & 46.56 & 26.60 \\
G.Green & 4185 & 3109 & 49.25 & 26.48 \\
Florispan & 2379 & 1664 & 48.60 & 23.78 \\
G.Red & 3942 & 2600 & 43.91 & 0.123 \\
LSD $\left(\% 5_{\mathrm{B}}\right)$ & 71.9 & 33.1 & 0.122 & 0.275 \\
LSD $\left(\% 5_{\mathrm{AxB}}\right)$ & 160.7 & 74.0 & 0.273 & \\
\hline
\end{tabular}

Pod yield of the varieties ranged from $2379 \mathrm{~kg} \mathrm{ha}^{-1}$ to $5866 \mathrm{~kg} \mathrm{ha}^{-1}$ in a two-year average. According to a twoyear average, the highest pod yield was obtained from Halisbey (5866 $\mathrm{kg} \mathrm{ha}^{-1}$ ) and the lowest from Florispan (2379 kg ha-1) among the varieties (Table 3). The difference between the peanut varieties was statistically significant for the pod yield per hectare. Duncan et al. (1978) suggested that the length of the pod filling period and the rate of pod establishment is the best explain the variation in peanut yield. The differences between the varieties for the pod yield originated from their genotypic background. Interaction between the harvesting times and varieties for the pod yield were significant in both years. Pod yield of the varieties ranged from 3376 to $7532 \mathrm{~kg}$ ha ${ }^{1}$. The highest pod yield value $\left(7532 \mathrm{~kg} \mathrm{ha}^{-1}\right)$ was obtained from the harvest of Halisbey variety made at the 170 DAS in a two-year average (Figure 2). Gulluoglu et al. (2017) and Arioglu et al. (2018) indicated that the pod yield per hectare of peanut varieties were ranged from 3666 to 8796 $\mathrm{kg} \mathrm{ha}^{-1}$ and from $3062 \mathrm{~kg} \mathrm{ha}^{-1}$ to $7615 \mathrm{~kg} \mathrm{ha}^{-1}$, respectively in main crop growing conditions in Cukurova region. Both of them reported that the highest pod yield was obtained from Halisbey (8796 $\mathrm{kg} \mathrm{ha}^{-1}$ and $\left.7615 \mathrm{~kg} \mathrm{ha}^{-1}\right)$ variety. This variety belongs to Virginia market type. The pod yield is higher in Virginia groups. For this the highest pod yield was obtained from Halisbey variety. The similar result was obtained by some other researchers (Ariglu and Isler, 1990a; Arioglu and Isler, 1990b; Asibuo et al., 2008; Canavar and Kaynak, 2008; Abouziena et al., 2013; Sarkees, 2015 and Sogut et al., 2016).

Kernel (seed) yield is more important than pod yield in peanut production. Kernel yield $\left(\mathrm{kg} \mathrm{ha}^{-1}\right)$ calculated by the pod yield $\left(\mathrm{kg} \mathrm{ha}^{-1}\right) \mathrm{x}$ shelling percentage $(\%)$. As it can be seen in Table 3 and 4, pod yield per hectare and shelling percentage was increased when the harvesting time delayed. According to a two-year average, the kernel yield per hectare varied between $2096 \mathrm{~kg} \mathrm{ha}^{-1}$ and $3693 \mathrm{~kg} \mathrm{ha}^{-1}$. The kernel yield was increased to $3693 \mathrm{~kg} \mathrm{ha}^{-1}$ from 2096 $\mathrm{kg} \mathrm{ha}^{-1}$, when the harvesting time delayed from 130 DAS to $170 \mathrm{DAS}$. The differences between the harvesting times were statistically significant for the kernel yield in a twoyear average. Gulluoglu et al. (2017) found that the kernel yield was $4202 \mathrm{~kg} \mathrm{ha}^{-1}$ in main crop growing season, it was decreased to $3729 \mathrm{~kg} \mathrm{ha}^{-1}$ in double crop growing season in Cukurova region. These results are in agreement with the findings of Hadler and Panda (2014), Sarkees (2015), Meena et al. (2015), Hatipoglu et al. (2017) and Zuza et al. (2017).

The differences between the varieties were statistically significant for the kernel yield per hectare. The kernel yield values of the peanut varieties varied between 1664 $\mathrm{kg} \mathrm{ha}^{-1}$ and $3508 \mathrm{~kg} \mathrm{ha}^{-1}$ in a two-year average. The highest kernel yield was obtained from Halisbey $(3508 \mathrm{~kg}$ $\mathrm{ha}^{-1}$ ) and the lowest from Florispan (1664 kg ha-1). Interaction between the harvesting times and varieties for the kernel yield were significant in both years. Kernel yield of the varieties ranged from 1105 to $4689 \mathrm{~kg} \mathrm{ha}^{-1}$. The highest kernel yield value (4689 $\mathrm{kg} \mathrm{ha}^{-1}$ ) was obtained from the harvest of Halisbey variety made at the 170 DAS in a two-year average (Figure 2). The shelling percentage was found higher in Florispan, G. Green and G.Red than Halisbey, but due to lower pod yield, the kernel yield was lower in these varieties. The similar results were found by the Sharma et al. (2013), Sarkees (2015) and Gulluoglu et al. (2017).

As it can be seen in Table 4, the differences between the varieties and harvesting times were statistically 
significant for the oil and protein content. Oil and protein content are important quality characteristics in peanut seed. The oil content of the varieties was increased to $48.98 \%$ from $45.80 \%$ when the harvesting time delayed to 170 DAS from 130 DAS. The oil content of peanut seed influences by genotypic variation, growing conditions and maturity. Court et al. (1984) reported that the oil content was $45.8 \%$ in 2 September it was increased to $47.8 \%$ in 12 October. Sattayarak (1997), Lu et al. (1997), Canavar and
Kaynak (2013), Gulluoglu et al. (2016) and Arioglu et al. (2018) reported that oil content was increased by delaying the harvesting times in peanut seeds. Mortley et al. (2004) findings suggested that vegetative and reproductive growth, as well as oil content of peanut in controlled environments are best at warmer temperatures of $28 / 24^{\circ} \mathrm{C}$ to $32 / 28^{\circ} \mathrm{C}$ than at cooler temperature of $20 / 16^{\circ} \mathrm{C}$ to $24 / 20^{\circ} \mathrm{C}$.

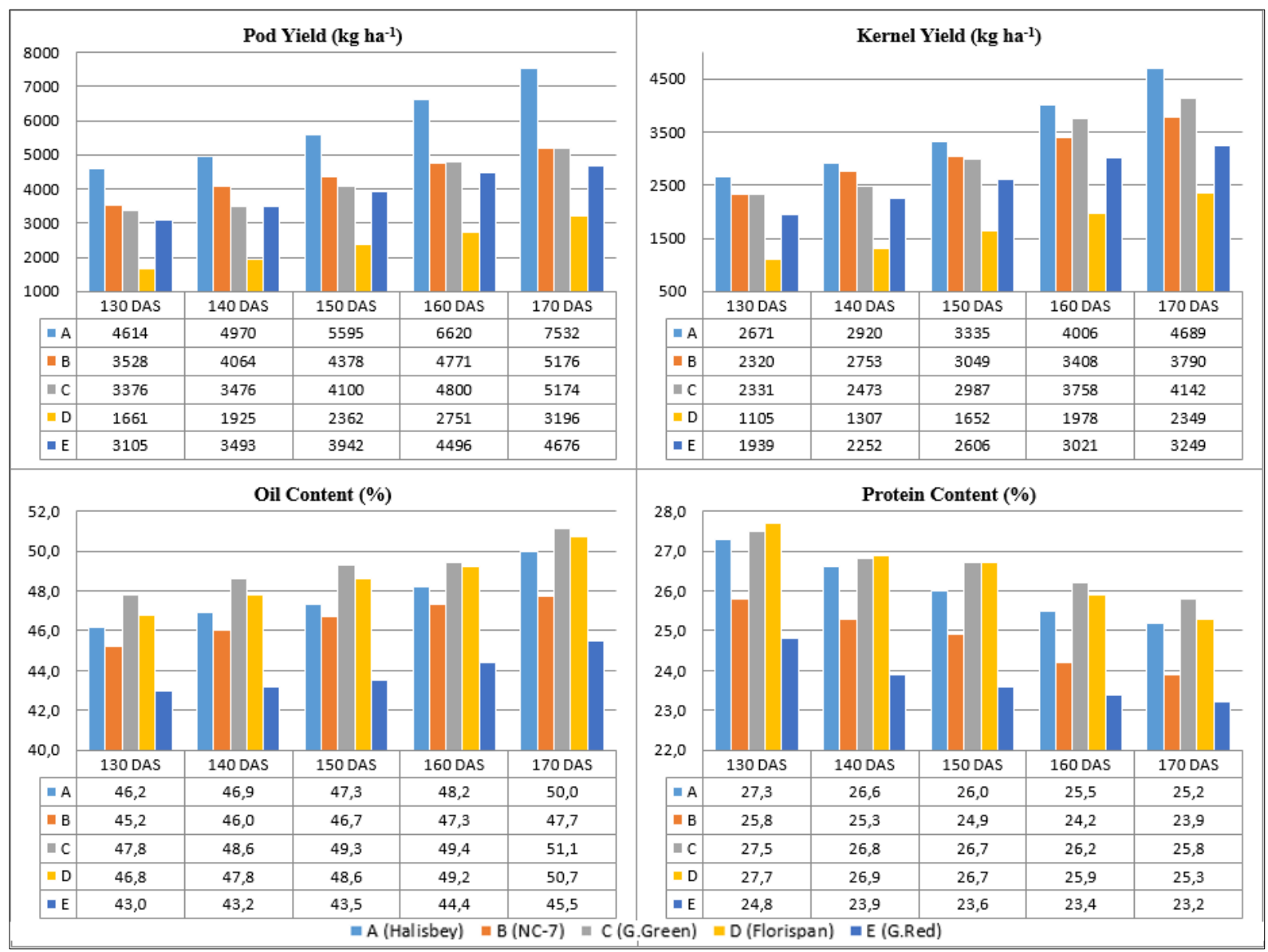

Figure 2. Interaction between the harvesting times and varieties for the pod and kernel weight per hectare, oil and protein content values in two years avarage

The protein content of the peanut varieties varied between $24.67 \%$ and $26.61 \%$ in a two-year average at different harvesting times. The protein content of the varieties was decreased when the harvesting delayed (Table 4). Gulluoglu et al. (2016) and Arioglu et al. (2018) found that the protein percentage was decreased from $25.60 \%$ to $24.65 \%$ and $25.68 \%$ to $23.02 \%$, when the harvesting time delayed from 148 DAP to 188 DAP and 149 DAS to 170 DAS, respectively in main crop growing conditions.

The oil content of the peanut varieties varied between $43.91 \%$ and $49.25 \%$ in a two-year average. The oil content was the highest in G.Green and the lowest in G.Red varieties (Table 4). Hassan et al. (2005) and Gulluoglu et al. (2017) reported that the oil percentage of peanut seed varies between $35 \%$ and $56 \%$ depending on genotype and growing conditions and the oil content of peanut varieties influence by genotype, seed maturity, climatic conditions, geographical location, growing season and growing conditions. Arioglu et al. (2018) found that the oil content of the peanut varieties varied between 45.6 and $50.0 \%$ in main crop growing season in Virginia market type varieties. Similar results were reported by some other researchers (Court et al., 1984; Sattayarak, 1997; Lu et al., 1997; Canavar and Kaynak, 2013 and Arioglu et al., 2017).

It can be seen in Table 4, the protein percentage of peanut varieties values varied between $23.78 \%$ and $26.60 \%$ in a two years average. The highest protein percentage was obtained from G.Green $(26.60 \%)$ and the lowest from G.Red $(23.78 \%)$ varieties. The protein content of peanut varieties is influence by genotype, seed 
maturity, climatic conditions, geographical location and growing season. Arioglu et al. (2018) reported that the protein percentage of peanut varieties varied between 23.13 and $25.41 \%$ in main crop growing season. These results are in agreement with the findings of Court et al. (1984), Sarkees (2015), Arioglu et al. (2017) and Gulluoglu et al. (2017).

Interaction between the harvesting times and varieties for the oil and protein content were significant in both years. Oil content of the varieties ranged from 43.0 to $51.1 \%$. The highest oil content value $(51.1 \%)$ was obtained from the harvest of G.Green variety made at the 170 DAS in a two-year average. Protein content of the varieties ranged from 23.2 to $27.7 \%$. The highest protein content value $(27.7 \%)$ was obtained from the harvest of Florispan variety made at 130 DAS in a two-year average (Figure 2).

\section{ACKNOWLEDGEMENTS}

This project (FDK-2015-4632) was supported by the Cukurova University Scientific Research Found (BAP).

\section{LITERATURE CITED}

Abouziena, H.F., S.D. Sharma and M. Singh. 2013. Impact of adjuvants on bentazon efficacy on selected broadleaf weeds. Crop Prot. 28: 1081-1085.

Anonymous, 2018. FAO Production Year Book (www.fao.org). (Accessed May 20, 2018)

Arioglu H., L. Gulluoglu and H. Bakal. 2017. The effect of harvesting times on yield and some agronomic characteristics of peanut varieties grown in main cropped condition in Mediterranean Region (Turkey). Second International Balkan Agriculture Congress, Congress Book, p.180-187, Tekirdag, Turkey

Arioglu, H. 2014. The oil seed crops growing and breeding. The publication of university of Cukurova, Faculty of Agriculture, No:A-70, 204 p. Adana-Turkey

Arioglu, H., H. Bakal, L. Gulluoglu, B. Onat and C. Kurt. 2018. The effect of harvesting dates on some agronomic and quality characteristics of peanut (Arachis hypogaea L.) varieties grown as a main crop in Mediterranean Region (Turkey). Turk J Field Crops. 23(1): 27-37.

Arioglu, H., N. Isler. 1990. A study on some Runner and Virginia peanut (Arachis hypogae L.) varieties that will be grown as main crops in the Cukurova region. C.U.A.F. Journal 5(3): 121-136.

Arslan, M., I. Uremis, S. Calıskan and N. Isler. 2005. Determination of early peanut varieties that can be grworn as double crop in eastern Mediterranean conditions. Turkey VI Field Crops Congress 5-9 Sep. 2005, Antalya, 2: 1141-1145.

Asibuo, J.Y., R. Akromah, H.K. Adu-Dapaah and O.S. Kantanka. 2008. Evaluation of nutritional quality of groundnut (Arachis hypogaea L.) from Ghana. African Journal of Food Agriculture Nutrition And Development 8: 133-149.

Caliskan, S., M.E. Caliskan, E. Erturk and H. Arioglu. 2008b. Growth and development of Virginia type groundnut cultivars under Mediterranean conditions. Acta Agric. Scan. B: Plant Soil Sci. 58: 105-113.

Caliskan, S., M.E. Caliskan, M. Arslan and H. Arioglu. 2008a. Effects of sowing date and growth duration on growth and yield of groundnut in a Mediterranean-type environment in Turkey. Field Crops Res. 105: 131-140.
Canavar, O. and M.A. Kaynak. 2008. Effect of different planting dates on yield and yield components of peanut (Arachis hypogaea L.). Turk. J. Agric. For. 32: 521-528.

Canavar, O. and M.A. Kaynak. 2010. Growing degree day and sunshine radiation effects on peanut pod yield and growth. African Journal of Biotechnology 9(15): 2234-2241.

Canavar, O. and. M.A. Kaynak. 2013. Determination of yield and yield components and seed quality of peanuts (Arachis hypogea L.) at Different Harvest Times. Int. J. of Agronomy and Plant Production. 4:3791-3803.

Chamberlin, K.D., N.A. Barkley, B.L. Tillman, J.W. Dillwith, R. Madden, M.E. Payton and R.S. Bennett. 2014. A comparison of methods used to determine the oleic/linoleic acid ratio in cultivated peanut (Arachis hypogaea L.). Agricultural Science 5(3):227-237.

Chowdhury, F.N., D. Hossain, M. Hosen and S. Rahman. 2015. Comparative study on chemical composition of five varieties of groundnut (Arachis hypogea L.). World J. of Agricultural Science. 11(5)247-254.

Court W.A., R.C. Roy and J.G. Hendel. 1984. Effect of harvest date on agronomic and chemical characteristics of Ontario peanuts. Canadian J. Plant Science. 64:521-528.

Duncan, W.G., D.E. McCloud, R.L. McGraw and K.J. Boote. 1978. Physiological aspects of peanut yield improvement. Crop Science 18:1015-1020.

Gulluoglu L., H. Bakal, B. Onat, C. Kurt and H. Arioglu. 2017. Comparison of agronomic and quality characteristics of some peanut (Arachis hypogaea L.) varieties grown as main and double crop in Mediterranean region. Turkish Journal of Field Crops 22(2): 166-177, DOI:10.17557/TJFC.356208.

Gulluoglu, L. 2011. Effects of regulator applications on pod yield and some agronomic characters of peanut in Mediterranean region. Turkish J. Field Crops. 16(2):210214.

Gulluoglu, L., H. Bakal, B. Onat, C. Kurt and H. Arioglu. 2016. The effect of harvesting date on some agronomic and quality characteristics of peanut grown in the Mediterranean Region of Turkey. Turk J Field Crops. 21(2): 224-232.

Halder, D. and R.K. Panda. 2014. Determination of appropriate planting dates and phosphorus fertilization strategy for peanut in eastern India. Afr. J. Agric. Res. 9: 2475-2487.

Hassan, F., A. Manaf and M. Ejaz. 2005. Determinants of oil and fatty acid accumulation in peanut. Int. J. of Agriculture and Biology. 7(6): 895-899.

Hatipoglu, H., H. Arslan, M. Karakus and S. Abrak. 2017. Determination of Some Peanut (Arachis hypogaea L.) Genotypes Suitable for Harran Plain Second Crop Conditions. Uludag University Agr. Journal. 31(1): 61-67.

Ishag, H.M. 2000. Phenotypic and yield response of irrigated groundnut cultivars in a hot environment. Exp. Agric. 36: 303-312.

Jordan D. L., S. Danésha, L. Carley, D. Cecil, B. S. Turner, R .L. Brandenburg and G. B. Michael. 2008. Peanut response to planting date and potential of canopy reflectance as an indicator of pod maturation. Agron. Journal. 100:376-380.

Kaba, J.S., K. Ofori and F.K. Kumaga. 2014. Inter-relationships of yield and components of yield at different stages of maturity in three groundnuts (Arachis hypogea L.) Varieties. International J. of Life Science Research. 2(1):43- 48.

Ketring, D. L., W. R. Jordan, O.D. Smith and C.E. Simpson. 1982. Genetic variability on root and shoot growth characteristics of peanut. Peanut Sci. 9:68-72.

Knauft, A., A.J. Norden and D.W. Gorbet. 1986. The effect of three digging dates on oil quality, yield, and grade of five peanut genotypes grown without leaf spot control. Peanut Science 13: 86-89. 
Kumar, A., M. Kumar and P. Virender. 2017. Effect of sowing time on growth, phenology and yield attribute of summer groundnut (Arachis hypogaea L.) in Allahabad. Int. J. Curr. Microbiol. App. Sci. 6(4):2357-2365.

Liao, B. and C. Holbrook. 2007. Groundnut. Singh, R.J. (Ed.), Genetic Researches, Chrosome Engineering, and Crop Improvement (51-87), CRC Pres, Vol. 4, New York, USA.

Lim, E.S. and O. Hamdan. 1984. The reproductive character of four varieties of groundnuts (Arachis hypogea L.). Pertanica 7:25-31.

Lu, K.C., M.S. Yeh, K.H. Yang and H.S. Lu. 1997. Effects of genotype, population density and harvest date on yield and quality of peanut. J. of Agric. Res. China. 46(2):116-131.

Meena V.S., S.K. Meena, J.P.Verma, R.S. Meena and B.N. Ghosh. 2015. The needs of nutrient use efficiency for sustainable agriculture. J Cleaner Prod. 102:562-563.

Mixon, A.C and W.D. Branch. 1985. Agronomic performance of a spanish and runner cultivar harvested at six different digging intervals. Peanut Science 12:50-54.

Mortley, D.G., C.K. Bonsi, W.A. Hill and C.E. Morris. 2004. Temperature influences yield, reproductive growth, harvest index, and oil content of hydroponically grown 'Georgia Red' Peanut. Plants Horticultural Science 39: 975-978.

Park, C.K. and J.H. Oh. 1992. Effect of cultural practice and harvest time on yield components of peanut. Korean J. Crop Science. 37(4): 347-354.

Rahmianna, A.A., A. Taufiq and E. Yusnawan. 2009. Pod yield and kernel quality of peanut grown under two different irrigations and two harvest times. Indonesian $\mathrm{J}$. of Agriculture. 2(2): 103-109.

Sarkees, N.A. 2015. Effect of sowing dates on development, seed yield and quality of some peanut (Arachis hypogaea L.) genotypes. Jordan J. of Agricultural Sciences. 11(2): 367380 .

Sattayarak, S. 1997. Effects of harvesting dates on different characters and seed quality of peanut grown in Southern
Thailand. http://agris.fao.org/agris-search/.do?recordID= TH2000000950

Sharma, P., V. Sardana and S.S. Kandhola. 2013. Effect of sowing dates and harvesting dates on germination and seeding vigor of groundnut (Arachis hypogaea L.) cultivars. Research J. of Seed Science. DOI: 10.3923/rjss: 1-15.

Sogut, T., F. Ozturk and S. K1z1l. 2016. Effect of sowing time on peanut (Arachis hypogaea L.) cultivars: I. yield, yield components, oil and protein content. Scientific Papers. Series A. Agronomy. 59: 415-420.

Timmannavar, M., P.N. Umapathy, M. Shekhargouda, B.M. Kurdikeri and A.S. Channveerswami. 2003. Influence of harvesting stages on seed yield and quality in confectioner groundnut varieties. Seed Research 31: 13-17.

Wang, Z. and Z. Xu. 2013. Effect of peanut Hull biochar on amelioration of typical orchard acidic soil in Northern China. Periodical Ocean Univ. China 43 (8) 86-91.

Williams, E. and. J.S. Drexler. 1981. A Nondestructive method for determining peanut pod maturity. Peanut Sci. 8: 134-141.

Williams, J.H . 2000. The implications and applications of resource capture concepts to crop improvement by plant breeding. Agric. For. Meteorol. 104: 49-58.

Wright, F.S. and D.M. Porter. 1991. Early Leaf Spot of Peanuts: Effect of Conservation Tillage Practices on Disease Development. Peanut Science 8:72-75.

Young, J. H., N.K. Person, J.O. Donald and W.D. Mayfield. 1982. Harvesting, Curing and Energy Utilization, pp.458485. In H.E. Pattee and C. T. Young (eds). Peanut Science and Technology. Amer. Peanut Res. Educ. Society Inc., Yoakum. TX, USA.

Zuza, E. A. Jnr, I.V.M. Muitia, R.L. Amane and A.M. Mondjana. 2017. Effect of harvesting time on groundnut yield and yield components in Northern Mozambique. Journal of Postharvest Technology 5 (2): 55-63. 